\title{
The occurrence of Anisakis larvae on hairtail, Trichiurus lepturus caught from the Pangandaran Waters, West Java, Indonesia
}

\author{
NISA QUROTA AYUN, LUTFI SEPTIANA DEWI, MURWANTOKO, EKO SETYOBUDI" \\ Department of Fisheries, Faculty of Agriculture, Universitas Gadjah Mada. Jl. Flora Gedung A-4, Bulaksumur, Sleman 55281, Yogyakarta, Indonesia. \\ Tel.: +62-274-551218, Fax.: +62-274-551218, ^email: setyobudi_dja@ugm.ac.id
}

Manuscript received: 9 December 2020. Revision accepted: 19 February 2021.

\begin{abstract}
Ayun NQ, Dewi LS, Murwantoko, Setyobudi E. 2021. The occurrence of Anisakis larvae on hairtail, Trichiurus lepturus caught from the Pangandaran Waters, West Java, Indonesia. Biodiversitas 22: 1378-1384. This study aimed to investigate the prevalence, mean intensity, and type of Anisakis larvae infecting hairtail (Trichiurus lepturus) caught at Pangandaran Waters, West Java, Indonesia. It was conducted using 869 samples sourced from local fishermen. The parameters measured were the total length and weight of each T. lepturus. Furthermore, parasitological examination was carried out to investigate the occurrence of Anisakis larvae in the fishes. The selected samples of Anisakis were identified through morphological and molecular analysis. The results showed that the larvae were found either free in the abdominal cavity of the fishes or coiled and attached to the serosal layer of the gastrointestinal tract, gonad, liver, and muscle. It also showed that their prevalence in the T. lepturus was at a moderate level (45.5\%), with the mean intensity at 4.4 larvae/fish. Moreover, the larvae were mostly in the abdominal cavity (89\%), as only a few were found in another part of the fishes. Morphological identification showed that Anisakis infecting the hairtail was Type I, which is characterized by the presence mucron and ventriculus without caecum.. Molecular analysis was carried out by sequencing the ITS region, and it confirmed that the nematode was Anisakis typica, which until recently was recognized as a non-zoonotic parasite.. These parasites were not present in the edible portion/muscle of the fishes, and had a relatively moderate prevalence and low intensity. Therefore, their presence posed a relatively low risk to human health. However, due to consumption patterns and the increasing popularity of seafood, being served raw or undercooked, the incidence of anisakiasis may increase in the future. In the other hand, the presence of these larvae might be used as a biological indicator for several ecological studies.
\end{abstract}

Keywords: Anisakis, Indian Ocean, infection, intensity, prevalence

\section{INTRODUCTION}

Hairtail (Trichiurus lepturus) has a broad geographical distribution and could be found in tropical and temperate waters worldwide (Cruz-Torres et al. 2014; Barbosa et al. 2011). This fish species is a commercially important fishery resource and an export commodity. The total production of T. lepturus worldwide amounted to 1,151 million tons (FAO 2020). Ministry of Marine Affair and Fisheries Republic of Indonesia (2012) reported the export destination countries from Indonesia were Japan, South Korea, Hong Kong, China, Taiwan, Vietnam, Thailand, Singapore, Malaysia, Australia, and Brazil, with a total volume of 10,227 tons. Moreover, the high demand for $T$. lepturus exports has led to the extensive fishing of the species in the Indian Ocean along the southern coast of Java, and in Pangandaran, West Java, Indonesia.

The Genus Anisaki (Family Anisakidae) are parasites that commonly infect marine organisms worldwide. Their life cycles involve crustaceans, fishes, cephalopods, and marine mammals acting as intermediate, paratenic or transport hosts and definitive hosts, respectively (Klimpel and Palm 2011). The occurrence of anisakid nematode in marine fishes is of great concern for human health. Thus, the parasite is included in a group that needs to be watched out for in fishery products (EFSAPanel on BIOHAZ 2010). Today, anisakiasis is a new area of focus in tropical medicine (Wiwanitkit \& Wiwanitkit 2016). This is because humans could be infected with anisakid nematodes due to the consumption of raw or undercooked fish. The infection causes several symptoms such as sudden epigastric pain, vomiting, nausea, diarrhea, or allergic reaction (Pozio 2013; Nieuwenhuizen 2016; Ivanovic et al. 2017). The occurrence of these nematodes in the fish muscle could reduce the product value since they are unappealing to consumers (Bao et al. 2019). However, besides their negative impact, the presence of anisakid nematodes have been developed as a useful biological indicator for various ecological studies such as stock characterization and discrimination, migratory movement, host diet, and feeding habits (Podolska et al. 2006; Mattiucci et al. 2015; Gomes et al. 2020).

Various fish species and cephalopods have been reported to be infected with Anisakis larvae. Their presence on fishes/cephalopods has been properly studied in Europe and America, while other regions have not conducted such studies properly (Molnar et al. 2006). Larval stages of this species are commonly found infecting $T$. lepturus or cutlassfish in several areas such as the southern coast of Central Java (Suadi et al. 2007; Setyobudi et al. 2007) Taiwan and Japan (Umehara et al. 2010), the southern coast of Yogyakarta (Setyobudi et al. 2011), Bali Strait (Semarariana et al. 2012), Coast of Rio de Janeiro, Brazil (Borges et al. 2012), Korea (Kim et al., 2016), Moroccan 
Atlantic coast (Youssir et al. 2017), and Northern Taiwan (Sonko et al. 2019). Furthermore, their presence has become a major concern, especially with respect to product safety and human health issues, ecological importance, and their use as biological indicators for various ecological studies.

A study related to the infection of Anisakis on marine fishes in Indonesia has been carried out. However, this number is still very small, especially when compared to the number of fish species or marine organisms that inhabit Indonesian waters. According to Palm et al. (2017), although the country's marine biodiversity is very high, information about fish parasites in its waters is still lacking. Therefore, this study aimed to determine the prevalence and mean intensity of Anisakis larvae infection on $T$. lepturus (Trichiurus lepturus) at Pangandaran Waters, West Java.

\section{MATERIAL AND METHODS}

\section{Sampling and Anisakis larva collection}

Hairtails (T. lepturus) were obtained from fishermen at Pangandaran Waters (Indian Ocean), West Java, Indonesia (Figure 1) from March to May 2017. In total 869 of these fish species were sampled in this experiment. Each fish sample was measured for its total length $(0.1 \mathrm{~cm}$ accuracy) and weighed ( $0.1 \mathrm{~g}$ accuracy). Also, they were dissected for anisakid observations. The organs examined are the abdominal cavity, muscle, liver, digestive tract, and gonads. Furthermore, the muscles were sliced and then observed with the naked eye. The collected nematodes were washed repeatedly in physiological saline solution, and then fixed/stored in absolute ethanol for further analysis. Subsequently, the Anisakid found were counted, and the number of individuals per infected organ was also ascertained. The parasites population descriptor was calculated according to Bush et al. (1997) where prevalence $(\mathrm{P})$ was the number of hosts infected with parasites divided by the total number of fish examined, expressed as a percentage, while the mean intensity (MI) was the average of infection of parasite among the infected fish, expressed as larvae/infected host.

\section{Morphological Identification}

Anisakis larva was cleared for morphological identification using glycerin: lactic acid: phenol: DW (2: 1: 1: 1) solution. Then, the Anisakis was soaked in a lactophenol solution for approximately 24 hours or until its internal organs were visible. The organs were then observed visually using a stereomicroscope. Morphological identification was determined through the width of the body, length of the oesophagus, ventriculus, and tail, the shape of ventriculus, and the presence of a mucron in the tail. Finally, the anisakids were photographed, and identification using the method by Murata et al. (2011).

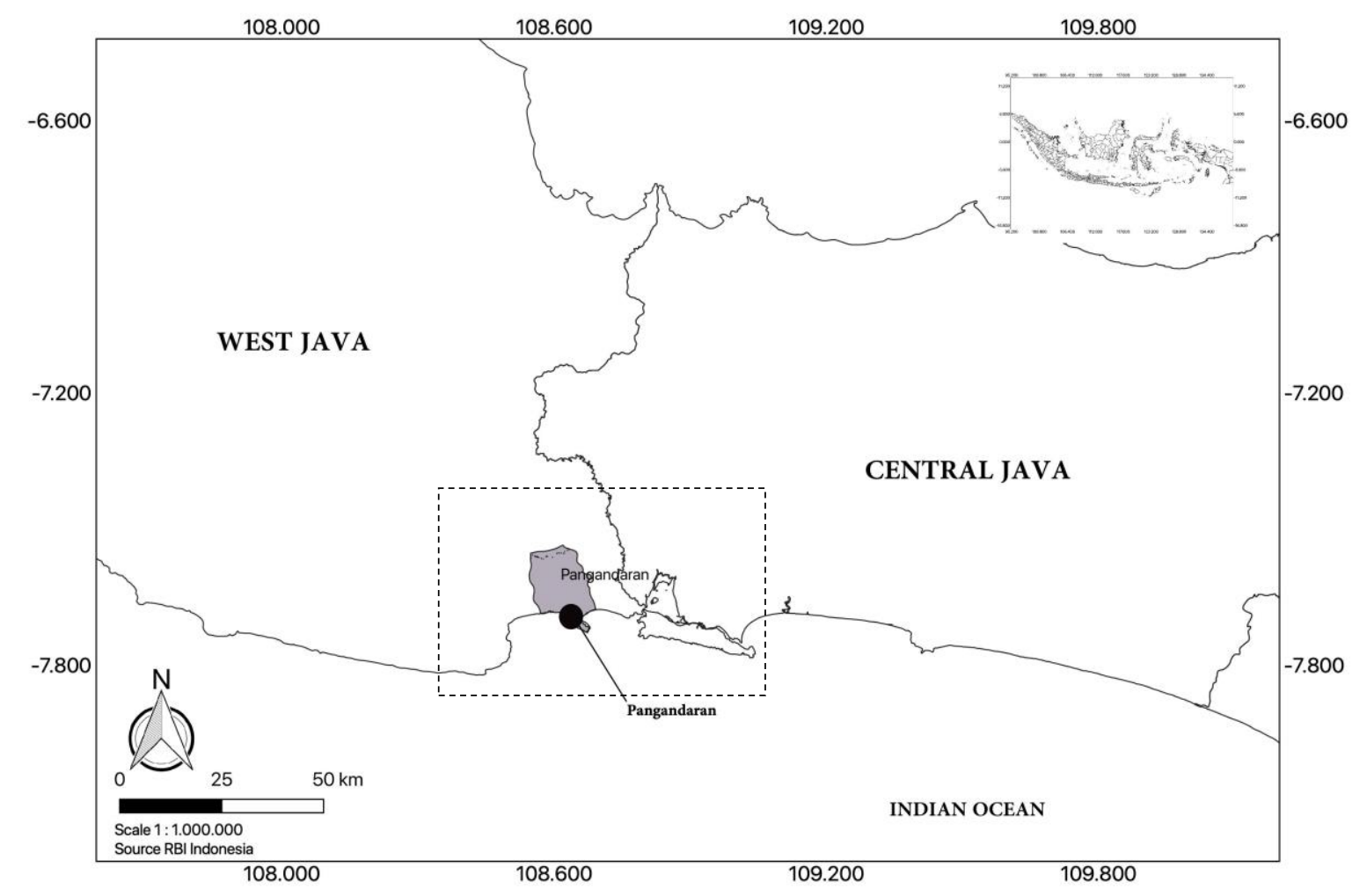

Figure 1. Sampling location and predicted fishing ground of T. lepturus capture at Pangandaran Waters, West Java, Indonesia 


\section{Molecular identification}

The genomic DNA of Anisakis was extracted from selected samples using Genomic DNA Mini Kit Tissue according to company instructions (Geneaid). Furthermore, the ITS region (ITS1-5.8S-ITS2) of rDNA was amplified using primers A (5'-GTC GAA TTC GTA GGT GAA CCT GCG GAA GGA TCA-3') and B (5'-GCC GGA TCC GAA TCC TGG TTA GTT TCT TTT CCT-3') (D'Amelio et al. 2000). DNA amplification was then carried out using PCR with the composition reaction of $0.5 \mu \mathrm{L}$ primer $\mathrm{A}$ and $\mathrm{B}, 6$ $\mu \mathrm{L}$ Kappa Mix (Kappa Biosystem), $5 \mu \mathrm{L}$ Nuclease Free Water, and $0.5 \mu \mathrm{L}$ of template DNA. Furthermore, the amplification process was carried out using Thermalcycler (Biorad, T100TM) under PCR conditions of predenaturation at $94^{\circ} \mathrm{C}$ for 10 minutes, 35 cycles of denaturation at $94^{\circ} \mathrm{C}$ for 40 seconds, annealing at $54^{\circ} \mathrm{C}$ for 40 seconds, extension at $72^{\circ} \mathrm{C}$ for 90 seconds, and lastly, final extension at $72^{\circ} \mathrm{C}$ for 7 minutes.

The PCR products were analyzed by electrophoresis in $1.5 \%$ agarose gel supplemented with $0.75 \mu \mathrm{L}$ Flourosave DNA stain (1st base). The electrophoresis was carried out for 15 minutes, and the result was photographed on a UV Transilluminator (Pacific Image, Electronic). The PCR product was then sequenced using a DNA sequencing service company (Singapore's 1st Base Laboratory through PT. Genetika Science Indonesia). The results of nucleotide sequences were verified using BioEdit software. Furthermore, the alignment nucleotide was analyzed using BLAST (Basic Local Alignment Search Tool) under NCBI (ncbi.nlm.nih.gov) website, and the phylogenetic was analysed by Mega 6.0 software (Tamura et al. 2013).

\section{RESULTS AND DISCUSSION}

\section{Results}

Hairtail (T. lepturus) caught at Pangandaran Waters, West Java was susceptible to Anisakis infection and had a relatively moderate prevalence $(395 / 869,45.5 \%)$ with a low mean intensity of infection (4.4 larvae/fish). Figure 2 shows the serious infection of Anisakis in the hairtail; the larvae were found either free or coiled in the abdominal cavity.Meanwhile, the prevalence and mean intensity of Anisakis are shown in Figure 3.

The highest prevalence $(92.9 \%)$ occurred in T. lepturus that were $56-60 \mathrm{~cm}$ in length, while the lowest prevalence $(32.7 \%)$ occurred in those at lengths of $36-40 \mathrm{~cm}$. Moreover, the prevalence and mean intensity of Anisakis infection increased in line with increase in body length. Therefore, the highest mean intensity of its infection occurred in the T. lepturus of $56-60 \mathrm{~cm}$ in length $(21.8$ larvae/fish).

Most of T. lepturus (83.8\%) were infected by Anisakis at low intensity ( $<5$ larvae/fish), while only a few (1.8\%) were infected at a high intensity (> 20 larvae/fish) (Figure 4).

The distribution of the target organ of Anisakis infection was shown in Figure 5. Anisakis was mostly found in the abdominal cavity (89\%), followed by the digestive tract $(4 \%)$, liver $(3 \%)$, gonads $(2 \%)$, and muscle $(2 \%)$.

Morphological identification showed that the anisakids infecting T. lepturus were Anisakis Type I. This type of Anisakis was found to be transparent white and have a tapered body. Furthermore, the anterior part of their body had a booring tooth characteristic of L3 larvae. The ventriculus had no caecum, while the posterior part of their body had a mucron (Figure 6).

The direct sequencing of ITS region of rDNA from two samples got 968 and 979 nucleotide, and have been deposited in Genbank with acession number MW541816 and MW541817, respectively. The molecular identification showed that the Anisakis larvae infecting the hairtails were Anisakis typica. (Figure 7; Table 1). A phylogenetic tree was constructed to explain the genetic relationship between A. typica isolated in this study with published sequences in the GenBank data. The phylogenetic tree reconstruction of these nematodes is presented in Figure 8.

Table 1. BLAST analysis of ITS rDNA of Anisakis infecting Trichiurus lepturus caught at Pangandaran Waters, West Java, Indonesia

\begin{tabular}{lllccc}
\hline Accession number & Species & Location & $\begin{array}{c}\text { Identical base pair } \\
(\text { bp) }\end{array}$ & $\begin{array}{c}\text { Percentage } \\
\text { identification }(\%)\end{array}$ & $\begin{array}{c}\text { Query cover } \\
(\%)\end{array}$ \\
\hline KC928262.1 & Anisakis typica & Indonesia & $915 / 916$ & $99.45 \%$ & $99 \%$ \\
AB432909.1 & Anisakis typica & Japan & $915 / 916$ & $99.56 \%$ & $99 \%$ \\
JX523715.1 & Anisakis typica & South China Sea & $911 / 912$ & $99.78 \%$ & $99 \%$ \\
HF911524.1 & Anisakis typica & North Red Sea & $915 / 916$ & $99.45 \%$ & $99 \%$ \\
KF673776.1 & Anisakis typica & South China Sea & $913 / 916$ & $99.34 \%$ & $99 \%$ \\
KX002228.1 & Anisakis typica & West India & $911 / 916$ & $99.22 \%$ & $99 \%$ \\
JN005760.1 & Anisakis typica & Portugal & $911 / 916$ & $99.01 \%$ & $99 \%$ \\
KF032062.1 & Anisakis typica & Turkey & $896 / 901$ & $99.32 \%$ & $99 \%$ \\
JX648312.1 & Anisakis typica & Papua New Guinea & $885 / 887$ & $99.66 \%$ & $99 \%$ \\
AY826724.1 & Anisakis typica & Brazil & $911 / 923$ & $98.36 \%$ & $99 \%$ \\
EU327691 & Anisakis physeteris & Brazil & $489 / 569$ & $85.94 \%$ & $54 \%$ \\
KY352231 & Anisakis brevispiculata & Brazil & $439 / 516$ & $85.08 \%$ & $49 \%$ \\
JX535521 & Anisakis simplex & Italy & $536 / 679$ & $78.94 \%$ & $92 \%$ \\
MH197040 & Anisakis pegreffii & Italy & $514 / 656$ & $78.35 \%$ & $86 \%$ \\
\hline
\end{tabular}




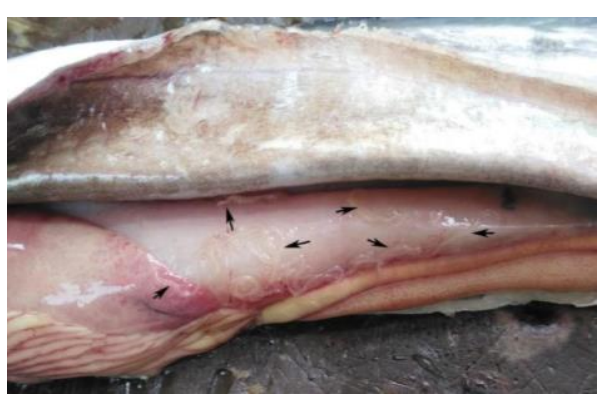

Figure 2. Infection of Anisakis on Trichiurus lepturus caught from the Pangandaran Waters, West Java, Indonesia

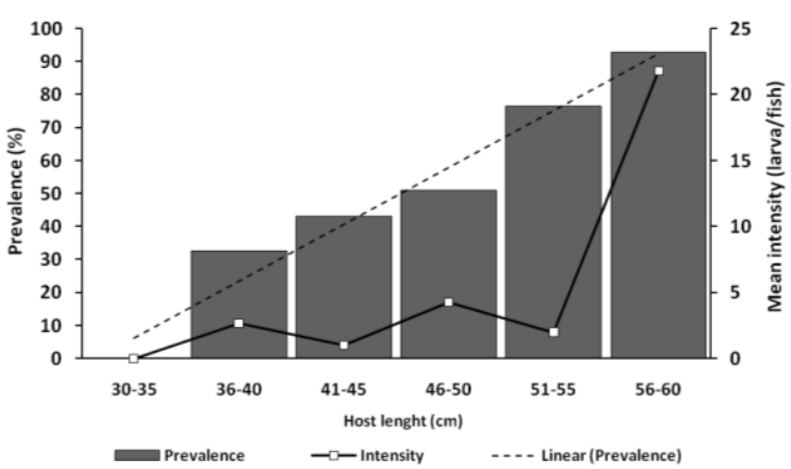

Figure 3. Prevalence and mean intensity of Anisakis on Trichiurus lepturus caught from the Pangandaran Waters, West Java, Indonesia

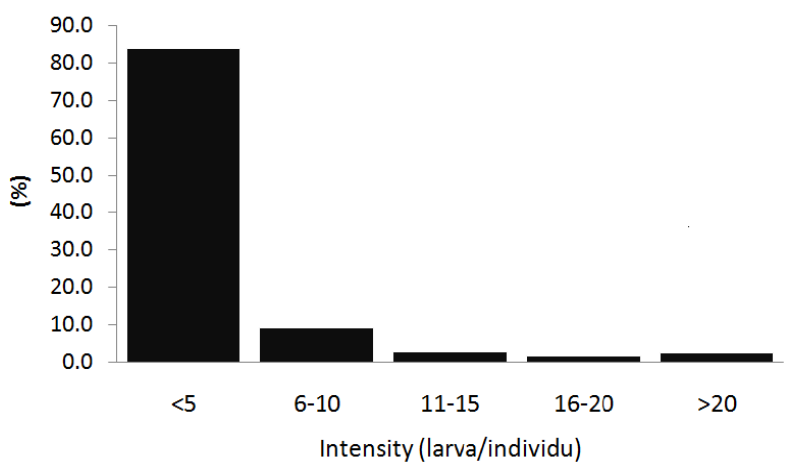

Figure 4. Intensity of the distribution of Anisakis infection on Trichiurus lepturus

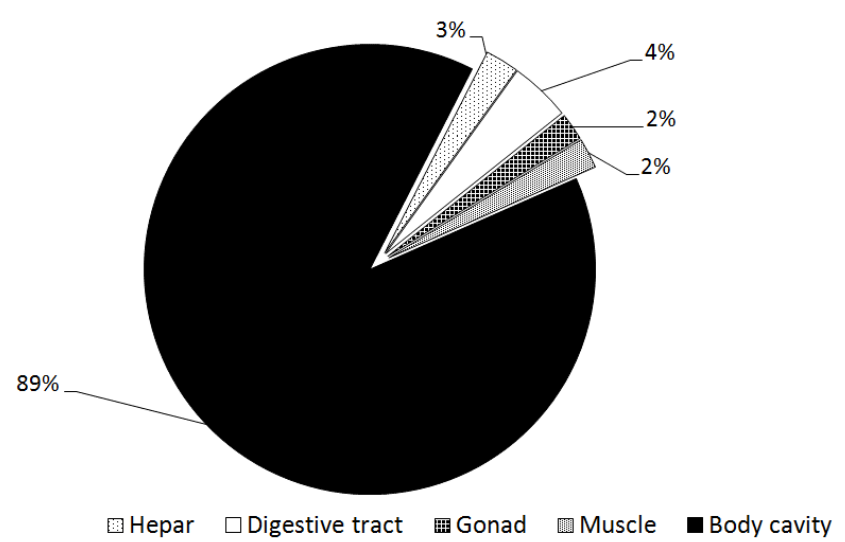

Figure 5. Target organ of Anisakis infection on Trichiurus lepturus caught from the Pangandaran Waters, West Java, Indonesia

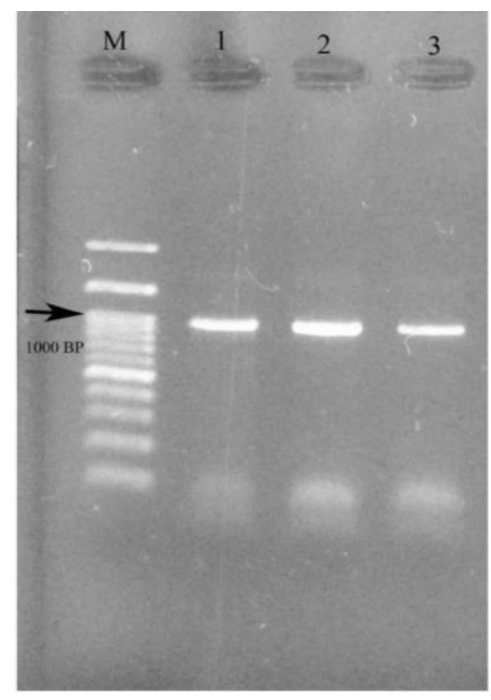

Figure 7. PCR result of Anisakis isolated from Trichiurus lepturus caught at the Pangandaran Waters, West Java, Indonesia

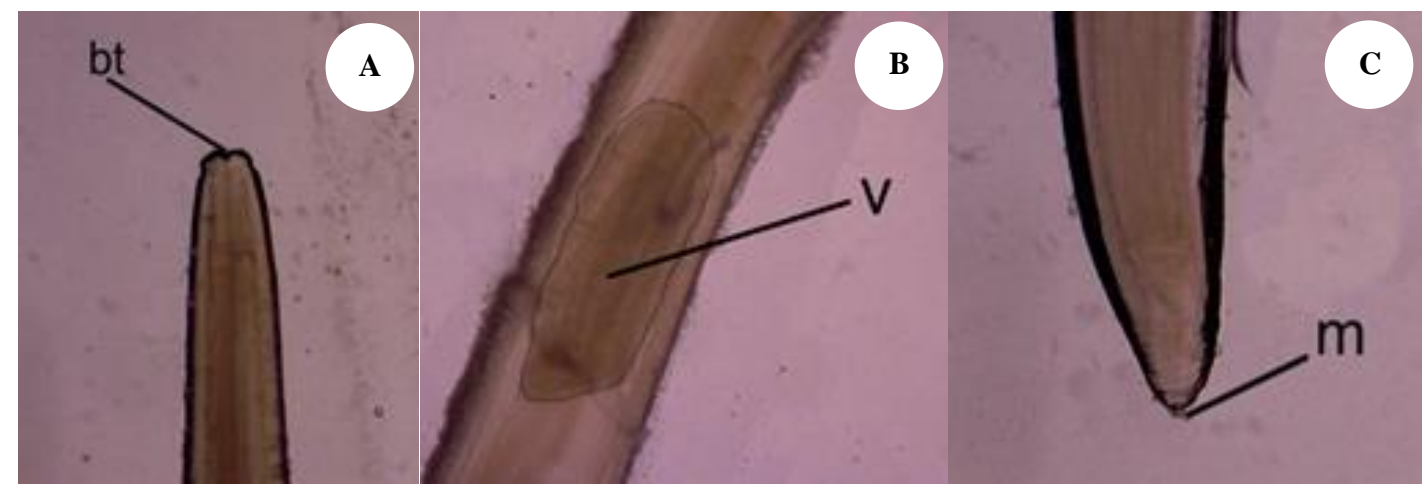

Figure 6. Anisakis morphology infecting Trichiurus lepturus caught from the Pangandaran Waters, West Java, Indonesia. A. Anterior. Bt: booring tooth; B. V: ventriculus; C. Posterior. M: mucron 


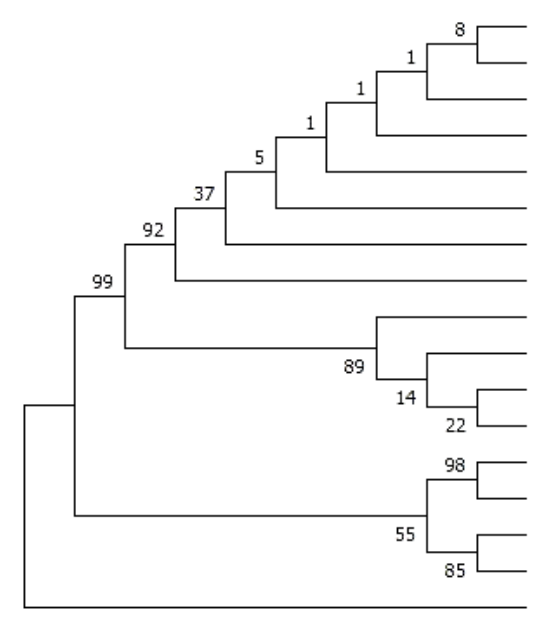

MW541816*

MW541817*

KC928262 A. typica Indonesia

JX648312 A. typica Papua New Guinea

JX523715 A. typica South China Sea

HF911524 A. typica Northern Red Sea

AB432909 A. typica Japan

KF673776 A. typica Southeast Coast of China

AY826724 A. typica Brazil

JN005760 A. typica Portuguese

KX002228 A. typica West Indies

KF032062 A. typica Turki

MH197040 A. pegreffii

JX535521 A. simplex

KY352231 A. brevispiculata

EU327691 A. physeteris

DQ116435 Pseudoterranova ceticola

Figure 8. Phylogram of Anisakis isolated from Trichiurus lepturus caught at the Pangandaran Waters, West Java, Indonesia obtained using maximum likelihood method (based on ITS region of rDNA)

\section{Discussion}

Hairtails (T. lepturus) caught at Pangandaran Waters, West Java were susceptible to anisakid larvae infection, with a relatively moderate prevalence of $45.5 \%$ and a low mean intensity of 4.4 larvae/fish. However, previous studies showed a high prevalence of Anisakis infecting this fish at $62.68-100 \%$ such as at the South coasts of Java and Purworejo Regency Central Java, and the North Taiwan Coast (Jacob and Palm 2006; Setyobudi et al. 2007; Sonko et al. 2019). Also, Semarariana et al. (2012) noted a relatively high intensity of this infection (9.2 larvae/fish) in $T$. lepturus caught at Bali waters. The high intensity of infection could be due to several reasons, such as climate change, and the abundance and size of the definitive hosts (Sonko et al. 2019).

In this study, Anisakis was mostly found in the body cavity at $89.1 \%$ and rarely in other parts. This is because when this nematode enters the body of its host through ingestion and survive in the digestive tract, it might migrate to the body cavity, which is an appropriate micro habitat for the species. Meanwhile, this location is appropriate due to its fat content, which is a source of nutrition for the nematode (Strømnes 2014). A parasitic microhabitat is an environment that supports parasite life, due to the availability of food, oxygen, or other factors (Williams and Jones 1994). Previous studies indicated that Anisakis was dominant in the body cavity of the host and was rarely in fish meat (Palm et al. 2017). However, in some cases, for example in salmon chum (Oncorhynchus keta) in Ishikari River, A. simplex infection occurs almost entirely in muscle (97.3\%) (Gomes et al 2020), because this nematode has a higher ability to migrate from the visceral organs to fish muscles compared to other Anisakis species (Suzuki et al. 2010; Bahlool et al. 2012).

The prevalence and intensity of Anisakis infection tend to increase with an increasing body length of its host. Furthermore, Abattuoy et al. (2011) mentioned that the presence of parasites would increase with the age and size of the host fish. This is because larger fishes usually of older age, thus consume a much higher amount of food compared to young fish. This in turn could increase the risk of Anisakis infection. The presence and prevalence of anisakid indicate the level of zoonosis, where the higher the prevalence value, the greater the risk of health problems for humans that consume it (Al-Zubaidy 2010).

Morphological identification confirmed that the Anisakis isolated from T. lepturus caught at Pangandaran Waters was Type I as they were characterized by long ventriculus and the existence of mucron in their tails (Borges et al. 2012; Sonko et al. 2019). Furthermore, till presently, this is the type of Anisakis larvae mostly found in Indonesia waters, and they are considered to have a wide distribution throughout the world (Mattiucci et al. 2018).

Molecular identification confirms that the Anisakis larvae infecting T. lepturus were Anisakis typica, which has a wide distribution from $35-40{ }^{\circ} \mathrm{N}$ to $36{ }^{\circ} \mathrm{S}$ in warm and tropical climates. Furthermore, its larva was found infecting several marine fishes around the world. The final hosts of this nematode are marine dolphins, such as bottlenose (Delphinidae) and La plata dolphins (Pontoporiidae) (Iñiguez et al. 2011; Shamsi et al. 2017).

Indonesian waters are an important world migration area for 33 marine mammal species. Furthermore, more than one-third of all species of whales and dolphins (cetaceans) could be found in these waters, distributed throughout the coastal waters to the deep sea, both settling and migrating (Salim 2011). Cetaceans are recognized as the definitive host for Anisakis typica, thus, they are a medium that distributes the nematode to all territorial waters in Indonesia. Consequently, the larvae of A. typica have been reported infecting several fishes in this country's waters such as Java and Bali waters (Palm et al. 2008), southern coast of East Java (Setyobudi et al. 2019), Makassar Strait (Anshary et al. 2014) and Savu Sea, East Nusa Tenggara (Soewarlan et al. 2014). The presence of Anisakis Type II has not been reported in the Indian Ocean southern coast of Java. This is supported by Mattiuci and Nascetti (2006), which stated that this type of Anisakis was 
not found in Asian waters but only in the Middle East and South Africa. Additionally, the final host of this nematode was sperm whales (Kogiidae and Physeteridae).

The A. typica from Pangandaran has a close genetic relationship with that from Indonesia and Papua New Guinea's waters. The proximity of genetic relationship level might be due to the geographical location that made possible the gene flow between those waters. A close genetic relationship was also shown with the A. typica from the South China Sea, which geographically is quite far. The wide distribution of Anisakis and its close genetic relationship might be affected by the migration of its final hosts which are dolphins (Kuhn et al. 2016).

The presence of Anisakis larvae in marine fishes is of great concern to human health, product safety, and ecological interests. Anisakis infection in humans is caused by consuming raw or undercooked fish such as sushi, sashimi, and others. The symptoms include nausea, vomiting, diarrhea, or an allergic reaction. These reactions are caused by chemical compounds found in the fish meat, which are produced by the parasite (Ivanovic et al. 2017; Kochanowski et al. 2020). Cases of anisakiasis that has been reported were mostly caused by $A$. simplex and $A$. pegrefii (Baird et al. 2014; Aibinu et al. 2019) meanwhile, those caused by A. typica are not yet widely known and receive relatively less attention, therefore, the zoonotic effect may also be underestimated (Umehara et al. 2010). Moreover, A. typica infection cases were not commonly reported probably due to the lack of information about the infection caused by its larva (Tunya et al. 2020).

Anisakis nematodes could cause massive infections in fishes which may lead to substantial damage of the host (Molnar et al. 2006). Several studies have shown that these nematodes infect most of the fishes caught from seas, meanwhile, cultured fishes are rarely infected (Mo et al. 2014; Brooker et al. 2016). The presence of these larvae in fish flesh causes a low aesthetic appeal to consumers and reduces the value of product (Bao et al. 2019). Therefore, it is necessary to examine Anisakis infection before fish processing. The fillets with serious infection need to be trimmed or discarded (Levsen and Karl 2014). This process is important not only to reduce economic losses but also to prevent anisakiasis in humans. Besides the negative impact, the presence of this nematode has been widely used as biological tags for various fishery biology studies (MacKenzie 2002; Baldwin et al. 2011; Mattiucci et al. 2015; Vasconcelos et al. 2017; Gomes et al. 2021). Therefore, Anisakis was recognized as one of the best biological markers among parasite species that have been used in the definition of fish stocks (MacKenzie 2002). The trends in the use of parasites as biological tags have significantly increased in the last decade. However, in order to use these organisms as biological tags, other information such as distribution and migration of the final host is needed.

This study confirms that T. lepturus is a commercially important fishery resource and export commodity that is susceptible to Anisakis infection. Therefore, it is necessary to periodically investigate the infestations of this fish in various geographic regions by the larvae of this parasite.
There are no reports regarding cases of anisakiasis in Indonesia (Wiwanitkit and Wiwanitkit 2016), although some fish species in the country's waters are susceptible to anisakid infection. However, due to consumption patterns and the increasing popularity of seafood being served raw or undercooked, the risk of anisakiasis may occur in the future.

\section{ACKNOWLEDGEMENTS}

This research was funded by Universitas Gadjah Mada, Yogyakarta, Indonesia, with contract number: 1725/UN1/DITLIT/DIT-LIT/LT/2020.

\section{REFERENCES}

Abattuoy N, Valero A, Benajiba MH, Lozano J, Martin-Sanchez J. 2011. Anisakis simplex (s.l.) parasitization in mackerel (Scomber japonicus) caught in the North of Morocco- Prevalence and analysis of risk factor. Intl J Food Microbiol 150: 136-139.

Aibinu IE, Smooker PM, Lopata AL. 2019. Anisakis Nematodes in fish and shellfish-from infection to allergies. IJP: Parasites and Wildlife (9): 384-393.

Al-Zubaidy AB. 2010. Third-stage larvae of Anisakis simplex (Rudolphi, 1809) in the Red Sea Fishes, Yemen Coast. JKAU Mar Sci 21 (2): 95112.

Anshary H, Sriwulan, Freeman MA, Ogawa K. 2014. Occurrence and molecular identification of Anisakis Dujardin, 1845 from Marine Fish in Southern Makassar Strait, Indonesia. Korean J Parasitol 52: 9-19.

Bahlool QZM, Skovgaard A, Kania P, Haarder S, Buchmann K. 2012. Microhabitat preference of Anisakis simplex in three salmonid species: Immunological implications. Vet Parasitol 190: 489-495.

Baird FJ, Gasser RB, Jabbar A, Lopata AL. 2014. Foodborne anisakiasis and allergy. Mol Cell Probes. 28: 167-174.

Baldwin RE, Rew MB, Johansson ML, Banks MA, Jacobson KC. 2011. Population structure of three species of Anisakis Nematodes recovered from Pacific Sardines (Sardinops sagax) distributed throughout the California current system. J Parasitol 97 (4): 545-554.

Bao M, Pierce GJ, Strachan NGC, Pascual S, Gonzalez-Munoz M, Levsen A. 2019. Human health, legislative and socioeconomic issues caused by the fish-borne zoonotic parasite Anisakis: Challenges in risk assessment. Trends Food Sci Technol 86: 298-310.

Barbosa SCT, Costa MF, Barletta M, Dantas DV, Kehrig HA, Malm O. 2011. Total mercury in the fish Trichiurus lepturus from a tropical estuary in relation to length, weight, and season. Neotrop Ichthyol 9 (1): 183-190.

Borges JN, Luiz FGC, Helena LCS, Cassiano M, Claudia PS. 2012. Morphological and molecular diagnosis of Anisakid nematode larvae from cutlassfish (Trichiurus lepturus) off the Coast of Rio de Janeiro, Brazil. PLoS ONE 7 (7): e40447. DOI: 10.1371/journal.pone.0040447.

Brooker AJ, Wootten R, Shinn AP, Bron JE. 2016. An assessment of the potential for zoonotic parasitic nematode infections arising from the consumption of maricultured Atlantic halibut, Hippoglossus hippoglossus (L.), and rainbow trout, Oncorhynchus mykiss (Walbaum), in Scotland. Food Contr 66: 198-204.

Bush AO, Lafferty KD, Lotz JM, Shostak AW. 1997. Parasitology Meets Ecology on its Own Terms: Margolis et al. Revisited. J Parasitol 83: $575-583$.

Cruz-Torres JDL, Martinez-Perez JA, Franco-Lopez J, RamirezVillalobos AJ. 2014. Biological and Ecological Aspects of Trichiurus lepturus Linnaeus, 1758 (Perciformes: Trichiuridae) in Boca Del Rio, Veracruz, Mexico. American-Eurasian J Agric Environ Sci 14 (10): 1058-1066.

D'Amelio S, Mathiopoulos KD, Santos CP, Pugachev ON, Webb SC, Picanco M, Paggi L. 2000. Genetic markers in ribosomal DNA for the identification of members of the genus Anisakis (Nematoda: Ascaridoidea) defined by polymerase chain reaction-based retriction fragment length polymorphism. Intl J Parasitol 30: 223-226. 
EFSA Panel on Biological Hazards (BIOHAZ). 2010. Scientific Opinion on risk assessment of parasites in fishery product. EFSA J 8 (4): 1543. DOI: $10.2903 /$ j.efsa.2010.1543.

FAO. 2020. The State of World Fisheries and Aquaculture 2020 Sustainability in action. FAO, Rome. DOI: 10.4060/ca9229en

Gomes TL, Quaizon KM, Kotake M, Fujise Y, Ohizumi H, Itoh N, Yoshinaga T. 2021. Anisakis spp. in toothed and baleen whales from Japanese waters with notes on their potential role as biological tags. Parasitol Intl 80: 102228. DOI: 10.1016/j.parint.2020.102228.

Iñiguez AM, Carvalho VL, Motta MRA, Pinheiro DCSN, Vicente ACP 2011. Genetic analysis of Anisakis typica (Nematoda: Anisakidae) from cetaceans of the northeast coast of Brazil: New data on its definitive hosts. Vet Parasitol 178: 293-299.

Ivanovic J, Baltic MZ, Boskovic M, Kilibarda N, Dokmanovic M, Markovic R, Janjic J, Baltic B. 2017. Anisakis allergy in human. Trends Food Sci Technol 59: 25-29.

Jacob E, Palm HW. 2006. Parasites of commercially important fish species from the southern Java coast, Indonesia, including the distribution pattern of Trypanorhynch cestodes. Verhandlungen der Gesellschaft fur Ichthyologie 5: 165-191.

Kim JH, Nam WH, Jeon CH. 2016. Genetic identification of anisakid nematodes isolated from large head hairtail (Trichiurus japonicus) in Korea. Fish Aquatic Sci 19: 26. DOI: 10.1186/s41240-016-0026-8

Klimpel S, Palm HW. 2011. Anisakid Nematode (Ascaridoidea) Life Cycles and Distribution: Increasing Zoonotic Potential in the Time of Climate Change. Parasitol Res Monogr 2: 201-222.

Kochanowski M, Dabrowska J, Rozycki M, Karamon J, Sroka J, Cencek T. 2020. Proteomic profiling reveals new insights into the allergomes of Annisakis simplex, Pseudoterranova decipiens, and Contracaecum osculatum. J Parasitol 106 (5): 572-588.

Kuhn T, Cunze S, Kochman J, Klimpel S. 2016. Environmental variables and definitive host distribution: a habitat suitability modelling for endohelminth parasites in the marine realm. Sci Rep 6: 30246. DOI: 10.1038/srep30246.

Levsen A, Karl H. 2014. Anisakis simplex (s.I.) in Grey Gurnard (Eutrigla gurnardus) From the North Sea: Food safety considerations in relation to fishing ground and distribution in the flesh. Food Contr 36: 15-19.

MacKenzie K. 2002. Parasites as biological indicator of host population. Intl J Parasitol 17: 342-345.

Mattiucci S, Cimmaruta R, Cipriani P, Abaunza P, Bellisario B, Nascetti G. 2015. Integrating Anisakis spp. parasites data and host genetic structure in the frame of a holistic approach for stock identification of selected Mediterranean Sea fish species. Parasitology 142 (1): 90-108.

Mattiucci S, Cipriani P, Levsen A, Paoletti M, Nascetti G. 2018 Molecular epidemiology os Anisakis and anisakiasis: an ecological and evolutionary road map. Parasitology 99: 93-263.

Mattiucci S, Nascetti G. 2006. Molecular systematics, phylogeny and ecology of anisakid nematodes of the genus Anisakis Dujardin, 1845: an update. Parasite 13: 99-113.

Mo TA, Gahr A, Hansen H, Hoel E, Oaland O, Poppe TT. 2014. Presence of Anisakis simplex (Rudolphi, 1809 det. Krabbe, 1878) and Hysterothylacium aduncum (Rudolphi, 1802) (Nematoda; Anisakidae) in runts of farmed Atlantic salmon, Salmo salar L. J Fish Dis 37: 135-140.

Molnar K, Buchmann K, Szekely C. 2006. Phylum Nematoda. In: Woo PTK (ed.). Fish Disease and Disorders Vol 1: Protozoan and metazoan infections, 2nd. CAB International, Wallingford, UK

Murata R, Suzuki J, Sadamasu K, Kai A. 2011. Morphological and molecular characterization of Anisakis larvae (Nematoda: Anisakidae) in Beryxsplendens from Japanese Waters. Parasitol Intl 60: 193-198.

Nieuwenhuizen NE. 2016. Anisakis: immunology of a foodborne parasitosis. Parasite Immunol 38: 548-557.

Palm HW, Damriyasa IM, Linda, Oka IBM. 2008. Molecular genotyping of Anisakis Dujardin, 1845 (Nematoda: Ascaridoidea: Anisakidae) larvae from marine fish of Balinese and Javanese Water, Indonesia. Helminthologia 45: 3-12.

Palm HW, Theisen S, Damriyasa IM, Kusmintarsih ES, Oka IBM, Setyowati EA, Suratma NA, Wibowo S, Kleinertz S. 2017. Anisakis
(Nematoda: Ascaridoidea) from Indonesia. Dis Aquat Org 123: 141157.

Podolska M, Horbowy J, Wyszynski M. 2006. Discrimination of Baltic herring population with respect to Anisakis simplex larvae infection. J Fish Biol 68: 1241-1256.

Pozio E. 2013. Integrating animal health surveillance and food safety: the example of Anisakis. Ref Sci Tech Off Intl Epiz 32 (2): 487-496.

Salim D. 2011. Conservation of marine mammals (Cetacean) in the Savu Sea, East Nusa Tenggara. Indon J Mar Sci Technol 1 (4): 24-41. [Indonesian]

Semarariana IWY, Suratma INA, Oka IBM. 2012. Infection of Anisakis spp. larvae on hairtail (Trichiurus lepturus). Indonesia Medicus Veterinus. 1 (2): 293-304. [Indonesian]

Setyobudi E, Rohmah I, Syarifah RF, Ramatia L, Murwantoko, Sari DWK. 2019. Presence of Anisakis nematode larvae in Indian mackerel (Rastrelliger spp.) along the Indian Ocean southern coast of East Java, Indonesia. Biodiversitas 20 (1): 313-319.

Setyobudi E, Senny H, Soeparno. 2007. Anisakis sp.in hairtail (Trichiurus sp.) on the South Coast of Purworejo Regency. J Fish Sci 9 (1): 142148. [Indonesian]

Setyobudi E, Soeparno, Helmiati S. 2011. Infection of Anisakis sp. larvae in some marine fishes from the Southern Coast of Kulon Progo, Yogyakarta. Biodiversitas (12) 1: 34-37.

Shamsi S, Briand MJ, Justine J. 2017. Occurrence of Anisakis (Nematoda: Anisakidae) larvae in unusual hosts in southern hemisphere. Parasitology International 66 (6): 837-840.

Soewarlan, L. C., E. Suprayitno, Hardoko, and H. Nursyam. 2014. Identification of Anisakid nematode infection on skipjack (Katsuwonus pelamis L.) from Savu Sea, East Nusa Tenggara, Indonesia. Intl J Biosci 5 (9): 423-432.

Sonko P, Chen SC, Chou C, Huang Y, Hsu S, Barcak D, Oros M, Fan C. 2019. Multidisciplinary approach in study of the zoonotic Anisakis larval infection in the blue mackerel (Scomber australasicus) and the large head hairtail (Trichiurus lepturus) in Northern Taiwan. J Microbiol Immunol Infect 53 (6): 1021-1029.

Strømnes E. 2014. An in vitro study of lipid preference in whaleworm (Anisakis simplex, Nematoda, Ascaridoidea, Anisakidae) third-stage larvae. Parasitol Res 113: 1113-1118.

Suadi, Helmiati S, Widaningroem R 2007. Anisakis sp. parasites in hairtail (Trichiurus sp.) population landed in Cilacap Fishing Port. Journal of Fisheries Science 9 (2): 226-232. [Indonesian]

Suzuki J, Murata R, Hosaka M, Araki J. 2010. Risk factors for human Anisakis infection and association between the geographic origins of Scomber japonicus and anisakid nematodes. Il J Food Microbiol 137: 88-93.

Tamura K, Daniel P, Glen S, Sumitxl K. 2013. MEGA6: Molecular Evolutionary Genetics Analysis Version 6.0. Mol Biol Evol 30: 2725 2729.

Tunya R, Wongsawad C, Wongsawad P, Chai J. 2020. Morphological and molecular characteristics of Anisakis typica larvae in two species of threadfin bream, Nemipterus hexodon and $N$. japonicus, from the Gulf of Thailand. Korean J Parasitol 58: 15-21.

Umehara A, Kawakami Y, Ooi HK, Uchida A, Ohmae H, Sugiyama H. 2010. Molecular identification of Anisakis Type I larvae isolated from hairtail fish off the Coast of Taiwan and Japan. Intl J Food Microbiol 143: $161-165$.

Vasconcelos J, Hermida M, Saraiva A, Gonzalez GA, Gordo LS. 2017. The use of parasites as biological tags for stock identification of blue jack mackerel, Trachurus picturatus, in the North-Eastern Atlantic. Fish Res 193: 1-6. DOI: 10.1016/j.fishres.2017.03.015.

Williams H, Jones A. 1994. Parasitic Worms of Fish. Taylor and Francis, London.

Wiwanitkit S and Wiwanitkit V. 2016. Anisakiasis in Southeast Asia: A story of new tropical diseases. Asian Pac J Trop Biomed 6 (5): 382 383.

Youssir S, M'Bareck I, Shawket N, Hassouni T, El Kharrim K, Belghyti D. 2017. Cutlassfish infestation (Truchiurus lepturus) by Anisakis simplex larvae in Moroccan Atlantic Coast. J Entomol Zool Stud 5: 1857-1861. 